\title{
SZEMLÉLETVÁLTÁS A FELSŐOKTATÁSBAN: AZ ÁLTALÁNOS JÓLLÉT VIZSGÁLATA A NEUMANN JÁNOS EGYETEM PEDAGÓGUSKÉPZÖ KAR HALLGATÓI KÖRÉBEN
}

\section{CHANGE OF ATTITUDE IN HIGHER EDUCATION: ANALYSIS OF GENERAL WELL-BEING AMONG THE STUDENTS OF THE TEACHER TRAINING FACULTY OF JOHN VON NEUMANN UNIVERSITY}

\author{
Boda Tímea
}

Vezetés- és Szervezéstudományi Intézet, Debreceni Egyetem, Magyarország https://doi.org/10.47833/2021.1.ART.002

\section{Kulcsszavak: \\ szemléletváltás \\ felsőoktatás \\ általános jóllét \\ pedagógusképzés \\ Világgazdasági Fórum}

\section{Keywords:}

change of attitude

higher education

general wellbeing

teacher training

World Economic Forum

\section{Cikktörténet:}

Beérkezett 2021. március 10. Átdolgozva 2021. március 20. Elfogadva 2021. április 7.

\begin{abstract}
Összefoglalás
A tanulmány célja bemutatni, azokat a nemzetközi felsőoktatási tendenciákat, Világgazdasági Fórum Education 4.0 (WEF) iránymutatásokat, amelyek rámutatnak arra, hogy mindinkább szükségszerü a hallgatók azon képességeinek támogatása, amely az interperszonális készségekhez, az érzelmi intelligencia területekhez köthetőek, és amelyek meghatározhatják a hallgató általános jóllétét. A kutatás igazolja, hogy a pedagógushallgatók általános jólléte nem megfelelő, ezért annak fejlesztése már az egyetem keretein belül szükségszerü.
\end{abstract}

\begin{abstract}
The aim of the study is to present international higher education trends and the guidelines of the World Economic Forum's Education 4.0 (WEF), which point to the growing need to support students' abilities that can be linked to interpersonal skills, emotional intelligence areas, and that can define the student's overall well-being. The research verifies that the general wellbeing of pedagogical students is inadequate, so its development is already necessary within the university
\end{abstract}

\section{Bevezetés}

A pedagógus a pedagógushivatás megélésével, személyiségével, önazonosságával, általános jóllétével számos ponton hat a közösségre, így a gyermekek fejlödésére és az iskolai klímára is. Ennek sikerét azonban számos tényező nehezíti. Ezt támasztják alá a 2020-as adatok, miszerint 50\%-al csökkent az előző évhez képest a pedagógusképzésre jelentkezők száma és a pályát elhagyók száma is évröl évre emelkedik. Singh és Billingsley szerint a nem megfelelő jóllét elégedetlenséghez és gyakran a munka vagy akár a pálya elhagyásához is vezethet [1]. Berry

\footnotetext{
* Kapcsolattartó szerző. Tel.: +36 203972355

E-mail cím: boda.timea@econ.unideb.hu
} 
szerint az elégedettség és a mentális egészség is a pályán maradás-elhagyás fontos tényezője [2]. A tanulmány célja, hogy igazolja azt, hogy a pedagógushallgatók általános jólléte nem megfelelö, ezért szükségesek már az egyetemi képzés során azok a célirányos, a jóllétre fókuszáló fejlesztő folyamatok, amelyek később hozzájárulnak ahhoz, hogy a pedagógusok pozitívan éljék meg hivatásukat és a választott pályán maradjanak. A pedagógusok általános jólléte tehát fontos közösségi, társadalmi érdek.

$\mathrm{Ma}$, ami állandónak tekinthető, az maga a változás. Pár évtizeddel ezelőtt jellemzően a változás, változtatási cél kapcsán a változás területének felolvasztása, annak megváltoztatása majd befagyasztása volt jellemző [3]. Rohm szerint manapság e folyamat három eleméből kettőt tapasztalunk: a változtatni kívánt terület felolvasztása majd megváltoztatása [4]. A harmadik elem kimaradt. Ez állandó készültséget jelent a munkavállalók, így a pedagógusok részéröl is. Ahhoz, hogy a változás során a pedagógusok újra és újra megtapasztalják személyes hatékonyságukat, szükségesek azok a készségek, amelyek ezt a folyamatot támogatják. Ezen készségeket az egyetemi képzés során tudatosan szükséges fejleszteni, lehetőséget adva ezzel arra, hogy a hivatását megkezdő pedagógus a szakmai tudásán túl, személyi kompetenciáiban is megerősödve, a kihívásokat jól kezelve reziliensen és pozitív attitüddel kezdje el pedagógus-pályafutását. A gazdasági, társadalmi és technológiai szektorban megindult innovációk az oktatás területén is egyre sürgetöbbek. A McKinsey tanulmánya szerint a világ oktatási rendszerei nem tartanak lépést a gazdaság és a társadalom új igényeivel [5]. A Világgazdasági Fórum (WEF) rámutatott arra, hogy a 4. ipari forradalom megkövetelte képességekre nem lehet az 1. és a 2. ipari forradalom igényeire kifejlesztett oktatási módszertannal felkészíteni a fiatalokat [6]. A Világgazdasági Fórum amellett, hogy diagnosztizálta az Ipari Forradalom 4.0 és a Globalizáció 4.0 munkaerőpiaci és képzési igényeit, egy oktatási keretrendszert is kidolgozott melléjük. Az Oktatás 4.0 (Education 4.0) egy olyan oktatási keretrendszert képez, amely a fiatalokat a jövő várható és ismeretlen munkaköri követelményeire készíti fel [7]. Az Oktatás 4.0 (Education 4.0) az oktatás tartalmában és az oktatási élményben 8 jellemzőt ír le, ezek közül a 4. pont az Interperszonális készségek fejlesztését célozza meg, úgymint: érzelmi intelligencia, empátia, együttmüködés, tárgyalás, leadership és a szociális érzékenység [6]. Az érzelmi intelligenciához köthető egyik fontos terület az Általános jóllét. Bar-On modelljében megfogalmazza, hogy az érzelmi intelligencia egy olyan tudás és számos képességek sorozata, amely meghatározza azt, hogy valaki hogyan képes megbirkózni az őt ért környezeti hatásokkal. Modelljében a jóllét és a viselkedés elemeit hangsúlyozza [8].

A Cooper és Sawaf modell az eddigi modelleknél komplexebb módon értelmezi az érzelmi intelligencia fogalmát. Szerintük az érzelmi intelligencia egy olyan képesség, amely segítségével az egyén felfogja, megérti és hatékonyan ítéli meg az érzelmeket, mint az emberi energia, információ kapcsolatok és befolyás forrásait. Az ő értelmezésükben az érzelmi intelligenciára ható fontosabb tényezők: érzelmi műveltség, érzelmi edzettség, érzelmi mélység és érzelmi alkímia [9].

Az iskolai szervezetek légkörét a gyermekek észlelik, és ez indirekt módon befolyásolja közérzetüket és hatással van tevékenységükre. Tehát a pedagógus érzelmi intelligencia szintje hatással van az iskola, mint szervezet klímájára, és az ott tanuló gyermekek tevékenységére, hangulatára is [10]. Ma már számos szakirodalom alátámasztja azt, hogy az érzelmi intelligenciához köthető készségek szintje, így az Általános jóllét is, több mint $80 \%$-ban határozzák meg az eredményességet és a személyes hatékonyságot, akár változó környezetben is.

Az Oktatás 4.0 vezérelve szerint az oktatásnak azokat a kimeneti kompetenciákat szükséges fejlesztenie, amelyek a jövőbeni munkaerőpiacon elvárásként jelenhetnek meg a munkavállalókkal szemben, és amelyek a ma még ismeretlen követelményekhez való igazodás képességét teremtik meg. A felsőoktatásban új irányelv a képzés kimeneti szabályozása, ahol a fókuszban a kimeneti eredmények állnak, ahol a kompetencia alapú tanulás-tanítás lesz hangsúlyosabb és ezt a célt a tanulási eredmények alkalmazása szolgálja [11]. Ez egy olyan újfajta tanulási élmény, amely már több helyen megjelent, mint például a felsőoktatási szakok jogszabályban meghatározott Képzési és Kimeneti Követelményeiben (KKK), de a gyakorlatba rendszerszerüen még alig ment át. $A$ pedagógusképzésben a KKK-ban meghatározott követelmények eléréséhez szükségesek az új megoldások, módszertani innovációk. Ennek a korszerű szemléletnek lehet a pedagógusképzésben adekvát kísérője a pozitív pszichológia, amelyet a jóllét pszichológiájának is neveznek.

A Képzési és Kimeneti Követelményekben (KKK) megfogalmazott kompetenciák között az attitüd kompetencia-elem tartalmazza azokat az adott szakma müvelésével kapcsolatos nézeteket, 
motivációs, gondolkodási és cselekvési mintázatokat, a tanulásra és a munkára vonatkozó értékelő viszonyulásokat, amelyek az adott szakra egyedien jellemzőek. Az attitüdök megléte vagy hiánya a viselkedés és a verbális megnyilatkozások révén azonosítható [11] [12].

Ahhoz, hogy ezek a részelemek megvalósuljanak, a képzés során a pedagógushallgatóra, mint „teljes emberre” kell koncentrálnunk. Az attitüd elemeket hosszú távon akkor tudja elsajátítani a hallgató és magáénak érezni, ha az egyes elemek megélése során örömöt, pozitiv érzéseket él át és megtapasztalja ebben az önazonosságát, átéli az általános jóllétet. Átéli azt az egyensúlyi állapotot, amelyben jó lenni. Ez az állapot segíti őt a későbbiekben abban is, hogy a pályán maradjon. A pozitív pszichológia szemlélet alapú oktatás segíti a kimeneti kompetenciákra épülő élményalapú tanulási folyamat minden elemét (tudás, képességek, attitűd, autonómia és felelősségvállalás), azonban talán leginkább az attitüd kompetencia-elemben kézzelfogható.

\begin{tabular}{|c|c|}
\hline Szakok/KKK & Attitüd elemek \\
\hline $\begin{array}{c}\text { Csecsemö- és } \\
\text { kisgyermeknevelö } \\
\text { alapképzési szak }\end{array}$ & $\begin{array}{l}\text { - Nyitott a szimbolikus önkifejezési formák irányába, szívesen vesz részt művészeti } \\
\text { tevékenységekben. } \\
\text { - A kisgyermek és önmaga kreativitását örömmel éli meg. } \\
\text { - Személyiségét és tevékenységét a gyermek tisztelete, feltétel nélküli elfogadása } \\
\text { jellemzi. } \\
\text { - Befogadó és multikulturális szemlélettel rendelkezik. } \\
\text { - Problémaérzékenység, előítélet-mentesség, tolerancia, szociális érzékenység, } \\
\text { segítő attitűd és etikus magatartás jellemzi. } \\
\text { - Nyitott a gyermekek, családok és a szakmai közeg jelzéseire, partneri } \\
\text { kapcsolataiban együttmüködő. } \\
\text { - A megismert kisgyermeknevelői szerepekkel azonosul, képes azok hiteles } \\
\text { közvetítésére és felelősségteljes ellátására. }\end{array}$ \\
\hline $\begin{array}{l}\text { Óvodaped } \\
\text { alapképzé }\end{array}$ & $\begin{array}{l}\text { - Személyiségét előítélet-mentesség, tolerancia, szociális érzékenység, segítő } \\
\text { attitüd jellemzi, inkluzív és multikulturális szemlélettel rendelkezik, törekszik a } \\
\text { kulturális önazonosság megőrzésének, ápolásának elősegítésére és a } \\
\text { gyermekközösségbe történő beilleszkedés támogatására. } \\
\text { - Elfogadja, hogy az óvodai nevelés gyermekközpontú, befogadó, az óvodai } \\
\text { nevelésben alkalmazott pedagógiai hatásoknak a gyermek személyiségéhez kell } \\
\text { igazodniuk. } \\
\text { - Nyitott az újabb hazai és nemzetközi neveléstudományi kutatási eredmények, a } \\
\text { módszertani innovációk és az információs és kommunikációs technológiák kínálta } \\
\text { lehetőségek megismerésére és alkalmazására. }\end{array}$ \\
\hline $\begin{array}{c}\text { Tanitó alapképzési } \\
\text { szak }\end{array}$ & $\begin{array}{l}\text { - Tevékenysége során inkluzív, befogadó szemléletet képvisel, törekszik a } \\
\text { családok kulturális hagyományainak tiszteletben tartására. } \\
\text { - Tanítói tevékenysége minden területén elkötelezett a különböző szociokulturális } \\
\text { környezetböl érkező, a sajátos nevelési igényű, illetve a fogyatékos gyerekek } \\
\text { közösségbe történő beilleszkedésének támogatása iránt. } \\
\text { - Igényli az önreflexiót, a nevelési folyamat és saját tevékenysége több szempontú } \\
\text { elemzését, értékelését. } \\
\text { - Nyitott a munkájával összefüggő új elméletek és módszerek, a technológiai } \\
\text { lehetőségek, információs és kommunikációs technológiák megismerésére és } \\
\text { alkalmazására. } \\
\text { - Felkészültsége alapján részt vállal a tanító szakmával összefüggésben álló } \\
\text { kutatásokban, innovatív team-munkákban. }\end{array}$ \\
\hline
\end{tabular}




\section{1. sz. táblázat}

A pedagógusképzéshez köthetö KKK-ban megfogalmazott attitüd elemek, amelyek szoros kapcsolatban állnak a hallgatók általános jóllétével

Forrás: [13]

Az Egészségügyi Világszervezet definíciója szerint a mentális egészség a jóllét állapota; amelyben minden ember képes megvalósítani a benne rejlő lehetőségeket, képes megküzdeni az életben normálisan megjelenő stresszel, eredményesen és hatékonyan dolgozni és hozzájárulni közösségéhez [14]. Seligman Jól-lét elmélete azonban már összefüggéseket mutat a pozitív érzelem, az elmélyülés és az értelem között. Elméletének célja az örömállapot növelése azáltal, hogy növeljük a pozitív érzelmet, az elmélyülést, az értelmet, a pozitív kapcsolatokat és a teljesítményt [15]. Oláh szerint optimális jóllétről akkor beszélünk, amikor a szubjektív vagy érzelmi, a pszichológiai és a szociális jóllétmutatók egyaránt magasan állnak [16]. Diener megközelítésében „a jól-lét magába foglalja a boldogságot, az élettel való megelégedettséget, a pozitív érzelmi tényezőket, valamint számos szociális és egészségügyi haszonnal társul és kihívásokat tartalmaz" [17]. Ryff és Keyes szerint a jóllét, az ember által betöltött szerepre és az önmegvalósítás terén elért eredményekre fókuszál [18]. A jóllét nem csupán az elégedettség, a teljesítmény, de a pedagógus szakma és munkahely iránti elkötelezettség fontos meghatározója is. A jóllét egy olyan belső katalizátor, amely a motiváció erejét és tartósságát is meghatározhatja. Egy pedagógus sok olyan nehezítő tényezővel néz szembe, akár már a képzés során vagy a pályája elején is, amely arra késztetheti, hogy elhagyja ezt a szakmát és váltson. Goddard és munkatársai szerint ennek hátterében gyakran a kiégés áll, még a pályakezdő tanárok esetében is [2]. A magasabb jóllét érzésével bíró hallgatók hatékonyabban tanulnak, jobban reagálnak a stresszes helyzetekben, jobb problémamegoldó képességgel rendelkeznek, és egészséges személyiségként veszik fel a társadalmi, szakmai, vezetői szerepeket is [19], de akár a média által közvetített tömegnyomás ellen is felvértezik magukat [20] [21] [22]. Pusztai szerint a felsőoktatás feladata a hallgatói egészség és jóllét gondozása, hiszen a hallgató testi, lelki és érzelmi jólléte az eredményes tanulás meghatározó tényezője [23]. A jóllét elméletekben megfogalmazott komplex képességek a Világgazdasági Fórum Oktatás (WEF) 4.0 kerettervének több pontjában is megtalálhatóak. Többek között az Interperszonális képességek fejlesztésének (4. pont) is célja, hogy a hallgatónak képessé kell válnia arra, hogy saját jóllétét pozitív irányba tudja befolyásolni. Ehhez szükséges, hogy rendelkezzen a megfelelő önismerettel, tudatossággal, képes legyen felismerni szükségleteit és megfogalmazni céljait, ezáltal képes legyen alkalmazkodni a változásokhoz. A WEF első pontjaként kijelölt Globális polgár képességek fejlesztése megjelenik Kopp a „tanult sikeresség” meghatározásában is, mely szerint a „tanult sikeresség (eredményesség) - mint készség - elsajátítása a hallgatói időszak alatt növeli a hallgatók megküzdőképességét, az élettel való elégedettségét, a magasabb jóllét érzetet és megelőzésként hathat a stressz okozta megbetegedések kialakulására. A későbbi, segítő munkájukat is hatékonyabbá teheti, ha a hozzájuk fordulókban is ezt az attitüdöt tudják kialakítani" [24] [25]. A pedagógus mint minta tehát kulcs a gyermekek és a hallgatók személyiségfejlődésében. Bagdy megfogalmazásában: „A pedagógus alkotómunkája az emberformálás [26]. Egy 2020-ban a pedagógusok kiégését vizsgáló kutatás szerint a mai pedagógusokra leginkább a mindennapi konfliktusok, a megnövekedett óraszám, a gyermekek változása, mint kiégésére hajlamosító tényezők hatnak. A pedagógusok túlterheltek. Támogatásuk, általános jóllétük társadalmi érdek, hiszen a jövő generációja formálódik kezeik között.

\section{Módszerek}

A kutatást a Neumann János Egyetem Pedagógusképző Karán végeztem 2019-ben a szorgalmi időszakban. A kutatásban 333 fő óvópedagógus, tanító és csecsemő- és kisgyermeknevelő szakos pedagógushallgató vett részt, amiböl 153 fő nappali és 180 fő levelező tagozatos hallgató. A hallgatói jóllét mérésére az Egészségügyi Világszervezet WBI-5 (5 tételes Általános Jól-lét Index) magyar változatát használtam. A kérdőíveket SPSS 20 programmal dolgoztam fel. 


\section{Eredmények}

A mérőeszköz magyar populációra való adaptálása és validálása a Hungarostudy 2002 vizsgálat keretein belül történt meg. A WBI-5 belső megbízhatósága magas (Cronbach-alfa: 0,778$)$. A kérdőív Likert-skálával, 0-3 értékig méri a hallgatók elmúlt két hétre vonatkozó jellemzőit.

\begin{tabular}{|c|c|c|c|c|c|c|c|c|c|}
\hline \multirow[t]{2}{*}{$\begin{array}{c}\text { Az elmúlt két } \\
\text { hét során } \\
\text { érezte-e } \\
\text { magát }\end{array}$} & & \multicolumn{2}{|c|}{$\begin{array}{c}\text { egyáltalán } \\
\text { nem jellemző } \\
0\end{array}$} & \multicolumn{2}{|c|}{$\begin{array}{c}\text { alig jellemző } \\
1\end{array}$} & \multicolumn{2}{|c|}{$\begin{array}{c}\text { jellemző } \\
2\end{array}$} & \multicolumn{2}{|c|}{$\begin{array}{c}\text { teljesen jellemző } \\
3\end{array}$} \\
\hline & & $N$ & $\mathrm{~L}$ & $\mathrm{~N}$ & $\mathrm{~L}$ & $N$ & $\mathrm{~L}$ & $\mathrm{~N}$ & $\mathrm{~L}$ \\
\hline \multirow{4}{*}{$\begin{array}{l}1 . \\
\text {...vidámnak } \\
\text { és } \\
\text { jókedvűnek? }\end{array}$} & Óvó & 4 & 1 & 23 & 19 & 42 & 50 & 12 & 11 \\
\hline & TANÍTÓ & 6 & 3 & 17 & 9 & 17 & 29 & 11 & 8 \\
\hline & CSECSEMÖ & 1 & 0 & 5 & 8 & 13 & 25 & 2 & 17 \\
\hline & $\begin{array}{r}\text { ÖSZ: (Fö) } \\
(\%)\end{array}$ & $\begin{array}{r}11 \\
0,07\end{array}$ & $\begin{array}{l}4 \\
0,02\end{array}$ & $\begin{array}{l}45 \\
0,29\end{array}$ & $\begin{array}{l}36 \\
0,2\end{array}$ & $\begin{array}{l}72 \\
0,47\end{array}$ & $\begin{array}{l}104 \\
0,57\end{array}$ & $\begin{array}{l}25 \\
0,16\end{array}$ & $\begin{array}{l}36 \\
0,2\end{array}$ \\
\hline \multirow{4}{*}{$\begin{array}{l}\text { 2.... } \\
\text { nyugodtnak } \\
\text { és } \\
\text { ellazultnak? }\end{array}$} & ÓVó & 15 & 5 & 47 & 49 & 17 & 22 & 2 & 5 \\
\hline & TANÍTÓ & 12 & 6 & 24 & 20 & 9 & 17 & 6 & 6 \\
\hline & CSECSEMÖ & 1 & 4 & 13 & 20 & 7 & 16 & 0 & 10 \\
\hline & $\begin{array}{r}\text { ÖSSZ: (Fő) } \\
(\%)\end{array}$ & $\begin{array}{l}28 \\
0,18\end{array}$ & $\begin{array}{l}15 \\
0,08\end{array}$ & $\begin{array}{l}84 \\
0,55\end{array}$ & $\begin{array}{l}89 \\
0,49\end{array}$ & $\begin{array}{l}33 \\
0,21\end{array}$ & $\begin{array}{l}55 \\
0,30\end{array}$ & $\begin{array}{l}8 \\
0,05\end{array}$ & $\begin{array}{l}21 \\
0,11\end{array}$ \\
\hline \multirow{4}{*}{$\begin{array}{l}\text { 3. ... aktívnak } \\
\text { és élénknek? }\end{array}$} & Óvó & 7 & 3 & 38 & 26 & 33 & 43 & 3 & 9 \\
\hline & TANÍTÓ & 8 & 4 & 23 & 17 & 14 & 20 & 6 & 8 \\
\hline & CSECSEMŐ & 2 & 1 & 10 & 20 & 8 & 14 & 1 & 15 \\
\hline & $\begin{array}{r}\text { ÖSSZ: (Fő) } \\
(\%)\end{array}$ & $\begin{array}{l}17 \\
0,11\end{array}$ & $\begin{array}{l}8 \\
0,04\end{array}$ & $\begin{array}{l}71 \\
0,46\end{array}$ & $\begin{array}{l}63 \\
0,35\end{array}$ & $\begin{array}{l}55 \\
0,359\end{array}$ & $\begin{array}{l}77 \\
0,42\end{array}$ & $\begin{array}{l}10 \\
0,06\end{array}$ & $\begin{array}{l}32 \\
0,17\end{array}$ \\
\hline \multirow{4}{*}{$\begin{array}{l}4 . \ldots \\
\text { ébredéskor } \\
\text { frissnek és } \\
\text { élénknek? }\end{array}$} & ÓVó & 34 & 20 & 32 & 38 & 13 & 22 & 2 & 1 \\
\hline & TANÍTÓ & 17 & 14 & 23 & 16 & 8 & 15 & 3 & 4 \\
\hline & CSECSEMÖ & 8 & 7 & 12 & 21 & 1 & 17 & 0 & 5 \\
\hline & $\begin{array}{r}\text { ÖSSZ: (Fő) } \\
(\%)\end{array}$ & $\begin{array}{l}59 \\
0,38\end{array}$ & $\begin{array}{l}41 \\
0,22\end{array}$ & $\begin{array}{l}67 \\
0,43\end{array}$ & $\begin{array}{l}75 \\
0,41\end{array}$ & $\begin{array}{l}22 \\
0,14\end{array}$ & $\begin{array}{l}54 \\
0,3\end{array}$ & $\begin{array}{l}5 \\
0,03\end{array}$ & $\begin{array}{l}10 \\
0,05\end{array}$ \\
\hline \multirow{4}{*}{$\begin{array}{l}\text { 5. A napjai } \\
\text { tele voltak } \\
\text { számára } \\
\text { érdekes } \\
\text { dolgokkal? }\end{array}$} & ÓVÓ & 6 & 3 & 34 & 31 & 34 & 40 & 7 & 7 \\
\hline & TANÍTÓ & 5 & 2 & 23 & 20 & 14 & 18 & 9 & 9 \\
\hline & CSECSEMÖ & 1 & 1 & 8 & 17 & 11 & 22 & 1 & 10 \\
\hline & $\begin{array}{r}\text { ÖSSZ: (Fö) } \\
(\%)\end{array}$ & $\begin{array}{l}12 \\
0,07\end{array}$ & $\begin{array}{l}6 \\
0,03\end{array}$ & $\begin{array}{l}65 \\
0,42\end{array}$ & $\begin{array}{l}68 \\
0,37\end{array}$ & $\begin{array}{l}59 \\
0,38\end{array}$ & $\begin{array}{l}80 \\
0,44\end{array}$ & $\begin{array}{l}17 \\
0,11\end{array}$ & $\begin{array}{l}26 \\
0,14\end{array}$ \\
\hline
\end{tabular}

2. sz. táblázat

A NJE Pedagógusképző Kar hallgatói körében végzett jóllét vizsgálat eredményei

Forrás: saját forrás, saját szerkesztés

A kutatás eredményei rámutatnak arra, hogy a pedagógushallgatók koránt sem rendelkeznek az általános jóllétre jellemző tökéletes mentális és fizikai állapottal. Magasnak tekinthető például az az arány, amely szerint a nappali tagozatos hallgatók 36\%-a érezte magát egyáltalán nem, vagy alig jellemzően vidámnak és jókedvűnek. Továbbá a nappalis hallgatók 55\%-ára és a levelező hallgatók $49 \%$-ára az elmúlt két hét során alig volt jellemző az, hogy nyugodtak és ellazultak voltak. 
Kimagaslóan rossz eredmény nappali tagozaton $46 \%$ alig jellemzően érezte magát aktívnak és élénknek, levelező hallgatóknál $42 \%$-uk jellemzően érezte magát így. A nappalis hallgatók $81 \%-a$ és a levelezős hallgatók $63 \%$-a nem képes kellő energiával indítani a napját. Végül a nappalis hallgatók 42\%-ára alig jellemző, hogy érdekes dolgokkal találkozott az elmúlt két hétben, míg a levelezős hallgatók 44\%-ra jellemző ugyanez.

\section{Következtetések}

A kutatás eredményei igazolják, hogy a pedagógusképzésben résztvevő hallgatók nem kielégítően rendelkeznek azokkal a készségekkel, amelyek meghatározzák azt, hogy a mindennapjaikban az általános jóllétüket magas szinten éljék meg. A jellemzően húszas éveik elején járó fiatalok nem rendelkeznek kellő energiával és aktivitással, fáradtak. A nyugtalanságra és az ellazult állapotra vonatkozó adatok szerint jellemzően nem rendelkeznek a stresszoldáshoz, a rezilienciához szükséges képességekkel és technikákkal. Ha a pedagógushallgató birtokában van saját erőforrásainak ismeretével és képes is aktiválni azokat, akkor a hallgatónak jó esélyei vannak arra, hogy elkerülje a kimerülést és hosszú távon képes legyen fenntartani saját általános jóllétét és egészségét. A felsőoktatásban tehát célirányosan szükséges beépíteni azokat a támogató, fejlesztő programokat, amelyek segítik a hallgatók általános jólléthez szükséges érzelmi, fizikai és mentális erőforrásainak tudatosítását és fejlesztését.

\section{Irodalomjegyzék}

[1] Singh K.,Bonnies S., Billingsley (1996):Intent to Stay in Teaching: Teachers of Students with Emotional Disorders Versus Other Special Educators Remedial and Special Education, Hammil Institute on Disabilities http:/doi.org/10.1177/074193259601700105

[2] Bacsa-Bán, A. (2019). A szakmai pedagógusok (pedagógusi) pálya elhagyásának vizsgálata több dimenzióban. Educatio 6. évfolyam 3. szám Budapest, Kiadó: Budapesti Müszaki és Gazdaságtudományi Egyetem

[3] Molnár Edina (2017a) Korabeli magyar reklám és pszichológia. Alumni Kiadó, Szolnok

[4] Rohm A. (2016): Változásmenedzsment a szervezetekben Z-Press Kiadó, Miskolc

[5] McKinsey Global Institute (2017). Technology, jobs and the future of work. https://www.mckinsey.com/ /media/McKinsey/Featured\%20Insights/Employment\%20and\%20Growth/Technology\% 20jobs\%20and\%20the\%20future\%20of\%20work/MGl-Future-of-Work-Briefing-note-May-2017.ashx

[6] World Economic Forum (2020): SCHOOLS OF THE FUTURE. Defining New Models of Education for the Fourth Industrial Revolution. WEF, January 2020. Elérhető: http://www3.weforum.org/docs/WEF Schools of the Future Report 2019.pdf

[7] Boda T. (2020): A MediBall, mint újszerü eszköz a pedagógusképzésben résztvevő egyetemi hallgatók érzelmi intelligenciájának és általános jóllétének fejlesztésében Pozitív pedagógia és nevelés Konferencia Kötet I. Jobb Veled a Világ Alapítvány, Kiadó: Mentál Focus ISBN: 978-615-81691-1-0

[8] Bar-On, Reuven (2006). The Bar-On model of emotional-social intelligence. Psicothema, 18 Suppl, 13-25.

[9] Balázs, L. (2014). Érzelmi intelligencia. Miskolc: Z-Press Kiadó Kft

[10] Halász Gábor (1988): Az iskolai szervezet elemzése. Kutatási beszámló az iskolai szervezeti klíma empirikus vizsgálatáról. MTA Pedagógiai Kutatócsoport, Budapest.

[11] Tót, É. (2017). Segédlet a tanulási eredmények írásához a felsőoktatási szektor számára. Budapest, Oktatási Hivatal 12-14.

[12] Molnár Edina (2017b) Kommunikáció, meggyőzés, reklám. Alumni Kiadó, Szolnok

[13] EMMI 18/2016. (VIII. 5.) rendelet a felsőoktatási szakképzések, az alap- és mesterképzések képzési és kimeneti követelményeiről, valamint a tanári felkészítés közös követelményeiről és az egyes tanárszakok képzési és kimeneti követelményeiröl szóló 8/2013. (I. 30.) EMMI rendelet módosításáról Elérhető: https://net.jogtar.hu/jogszabaly?docid=A1600018.EMM\&txtreferer=00000001.TXT

[14] WHO: Mental Health, a state of well-being (Updated August 2014). http://www.who.int/features/factfiles/mental health/en/

[15] Seligman, Martin (2011). Flourish - élj boldogan! A boldogság és a jól-lét radikálisan új értelmezése. Budapest: Akadémiai Kiadó

[16] Oláh, A. \& Kapitány- Fövény, M. (2012). A Pozitív pszichológia tíz éve. Magyar Pszichológiai Szemle 67(1): 19-45 DOI: 10.1556/MPSzie.67.2012.1.3

[17] Diener, E., Emmons, R. A., Larsen, R. J., et al. (1985) The Satisfaction with Life Scale. J. Personality Assessment, 1985, 49(1), 71-75

[18] Szántó, Zs., Susánszky, É., Berényi, Z., Sipos, F., Murányi, I. (2016). A jól-lét fogalmának értelmezése az európai szakirodalomban (2009-2014) METSZETEK Vol. 5 (2016) No. 1 ISSN 2063-6415 DOI 10.18392/metsz/2016/1/6 Semmelweis Egyetem, Magatartástudományi Intézet, Debreceni Egyetem, Politikatudományi és Szociológiai Intézet

[19] Awartani, M., Whitman, C. V., Gordon, J (2008). Developing instruments to capture young people's perceptions of how school as a learning environment affects their well-being. Eur. J. Educ., 43(1), 51-70. 
[20] Molnár, Edina (2020a) The Role of the High Emotional Arousal Level in Purchasing Decisions Caused by Advertisements (August 3, 2020). SEA - Practical Application of Science, 2020, Available at SSRN: https://ssrn.com/abstract=3666009.

[21] Molnár Edina (2020b) The role of empathy, anxiety and personality in purchasing decisions caused by advertising. Annals of the University of Oradea. Economic Science, 29 (1), pp. 376-386.

[22] Molnár Edina (2020c) The role of momentary and sustained emotional arousal level in advertising-infulenced and non-influenced purhasing decisions..Cross-cultural Managament Journal, 22(1), pp. 67-78. RePEc:cmj:journl:y:2020:i:1:p:67-78

[23] Pusztai, G. (2011). From the invisible hand to friendly hands. Interpretive communities of students in higher education. (A láthatatlan kéztől a baráti kezekig. Hallgatói értelmező közösségek a felsőoktatásban.) Budapest, Új Mandátum Kiadó

[24] Kopp, M., Skrabski, Á., Szedmák, S. (2000) Psychosocial risk factors, inequality and self-rated morbidity in a changing society. Soc. Sci. Med.,51(9), 1351-1361.

[25] Molnár Edina (2012) Supervision in social work: experiences as a college supervisor of social worker training, Economica (Szolnok) 5, 2. különszám, pp. 29-35.

[26] Bagdy, E. (2002). Családi szocializáció és személyiségzavarok. Budapest, Nemzeti Tankönyvkiadó 